\title{
Departure from Indigenous Land Use System and the Consequential Impacts: A Case of Cuvelai Basin, North-Central Namibia
}

\author{
Johanna Ngula Niipele, Isak Kaholongo Kaholongo and Joseph Njunge \\ Department of Integrated Environmental Science, University of Namibia, Oshakati 9000, Namibia
}

\begin{abstract}
The Cuvelai Basin of north-central Namibia consists of unique seasonal wetlands made up of shallow pans locally known as Iishana (Oshana, singular) which form ephemeral network systems. The basin has relatively fertile soils encouraging human settlements. More than $40 \%$ of the country's population resides in the basin. Early settlers in the basin utilized indigenous knowledge to develop land use systems that were in harmony with biophysical characteristics of the area. Over the years, there has been a departure from these indigenous land use systems resulting in land management problems. A desktop study coupled with field observations was conducted to describe the indigenous land use systems of the Owambo people living in the basin, and to determine factors behind the departure and consequential impacts of this departure on sustainability of land uses. Possible ways of preventing erosion of this indigenous knowledge were given attention. The paper recommends that the Owamboindigenous land management system needs to be embedded within government policies and regulations and should be strictly enforced. There is also a need for designing strategic basin management plans that are a combination of both scientific and indigenous knowledge.
\end{abstract}

Key words: Cuvelai Basin, Owambo people, indigenous land use system, sustainable development.

\section{Introduction}

The Cuvelai Basin in north-central Namibia comprises a unique system of seasonal wetlands and constitutes some of the areas having the highest human population densities in Namibia (50-100 persons $\cdot \mathrm{km}^{-2}$ ). It was estimated that these wetlands carried about $25 \%$ of Namibia's population in 2001 [1]. This can partly be explained by the fact that the soils found in these wetlands are relatively fertile, by general standards of soils in Namibia, making them suitable for crop production. This, together with the seasonal availability of fresh surface water and the fact that the land is communally owned making it accessible to a large number of people, makes the four regions (Omusati, Ohangwena, Oshana and Oshikoto) within which the basin is found, the most densely populated rural areas in Namibia. The four regions carry about $40 \%$ of Namibia's population of about 2.2

Corresponding author: Isak Kaholongo Kaholongo, master, research field: forestry. E-mail: ikaholongo@unam.na. million people [2]. The geomorphology of the Cuvelai Basin is complex. Mendelsohn et al. [3] have provided a comprehensive description of the Cuvelai Basin landscapes and how the characteristics of these landscapes have influenced human settlement patterns. Typically, the Cuvelai wetlands are utilized for subsistence agriculture, pastoralism and a myriad of settlements. The woody vegetation of the basin is almost the sole source of energy, building and fencing materials [4]. This heavy utilization of the Cuvelai wetlands poses a high possibility of land degradation occurring, and indeed serious deforestation has been reported to have occurred in the last 100 years $[1,4,5]$. Salinization, soil compaction and depletion of soil nutrients could also be on the rise, only that they have not been keenly monitored.

The rapid increase in land degradation calls for a clear understanding of the structure and function of this system as a pre-requisite to prescribing sustainably sound land management practices that 
maximizes benefits while at the same time minimizing environmental degradation. Traditionally, communities living in these seasonal wetlands had a way of determining what areas to use for different land use practices. There is need to understand how such method sof land management were utilized and the positive aspects resulting from this indigenous knowledge in the current management practices of the basin. Such knowledge also needs to be documented and passed on to key playerscurrently involved in safeguarding land use and management practicesin the basin. In this light, a study was conducted to describe the biophysical characteristics of the Namibian Cuvelai Basin and the Owambo indigenous land management system, to determine factors contributing to the consequential impacts of this departure on sustainability of land uses and to recommend possible ways of preventing erosion of this indigenous knowledge.

\section{Material and Methods}

It was mainly a desktop study backed by field observations by the authors and interviews of key informants to verify information gathered from literature. Information was gathered from secondary sources (books, journal articles, and government reports among others). All matters that needed verification were noted as well as information gaps. Verification and gathering of extra information was attained through face to face interviews with key informants in Omusati Region and the Uukolonkadhi traditional authorities. Direct field observations were conducted on certain aspects of interest such as salinization, location of upcoming commercial centres in relation to waterways and the spread of crop fields into marginal areas.

\section{Results and Discussion}

3.1 The Biophysical Characteristics of the Cuvelai Basin in Namibia and Farming Systems

The upper parts of the Cuvelai Basin are in Angola, and the whole basin extends for a distance of about $450 \mathrm{~km}$ from north to south. The Namibian part of the Cuvelai Basin covers an area between the Okavango and Kunene Rivers and ends up in the Etosha Pan (Fig. 1). The basin covers an area of approximately 250,053 $\mathrm{km}^{2}$ from the Namibia-Angola border terminating in the Etasha Pan [6]. The Cuvelai lies within a relatively small depression along the western margins of the vast Kalahari Basin that covers much of south-central Africa. The basin is made up of shallow pans known as "Iishana", which form a network of shallow ephemeral river system. The areas between the Iishana consist of alluvial (clay) and Aeolian sediments (sands), making fertile soil substrates that may have encouraged farming and settlements in these seasonal wetlands some 500-600 years ago [7].

The area lies around altitude 1,000-1,150 m a.s.l. Total annual rainfall ranges between in 350-500 mm increases in a west-east gradient. Two distinct seasons are recognizable: hot, wet summers (November-April) and cool, dry winters (May-October). Due to high annual potential evapotranspiration, estimated to be between 1,680-2,100 mm, not much rain-fed crop production can be practiced for most part of the year. Kluge et al. [8] estimated the annual rainfall totals for the basin to range between $300-600 \mathrm{~mm}$ and potential annual evapotranspiration to be as high as $2,500 \mathrm{~mm}$. Summer temperatures can go as high as $30-36{ }^{\circ} \mathrm{C}$ and winter temperatures can fall to between $6-8^{\circ} \mathrm{C}[1]$.

The soils in the Cuvelai are basically of the Kalahari sands and clays resulting from water and wind deposition. They comprise of: eutriccambisols, cambicarenosols, hapliccalcisols and ferralicarenosols. The eastern part of the Cuvelai has infertile sand deposits. The soils in the central parts of the water channels (Iishana) are clayey and too saline for crop production. Among channels on higher grounds, a mixer of alluvial sediments and aeolian sediments form fertile cambisol and calcisol soils. These soils are mainly found in the central regions of the basin. The western side of the basin is mainly dominated by 


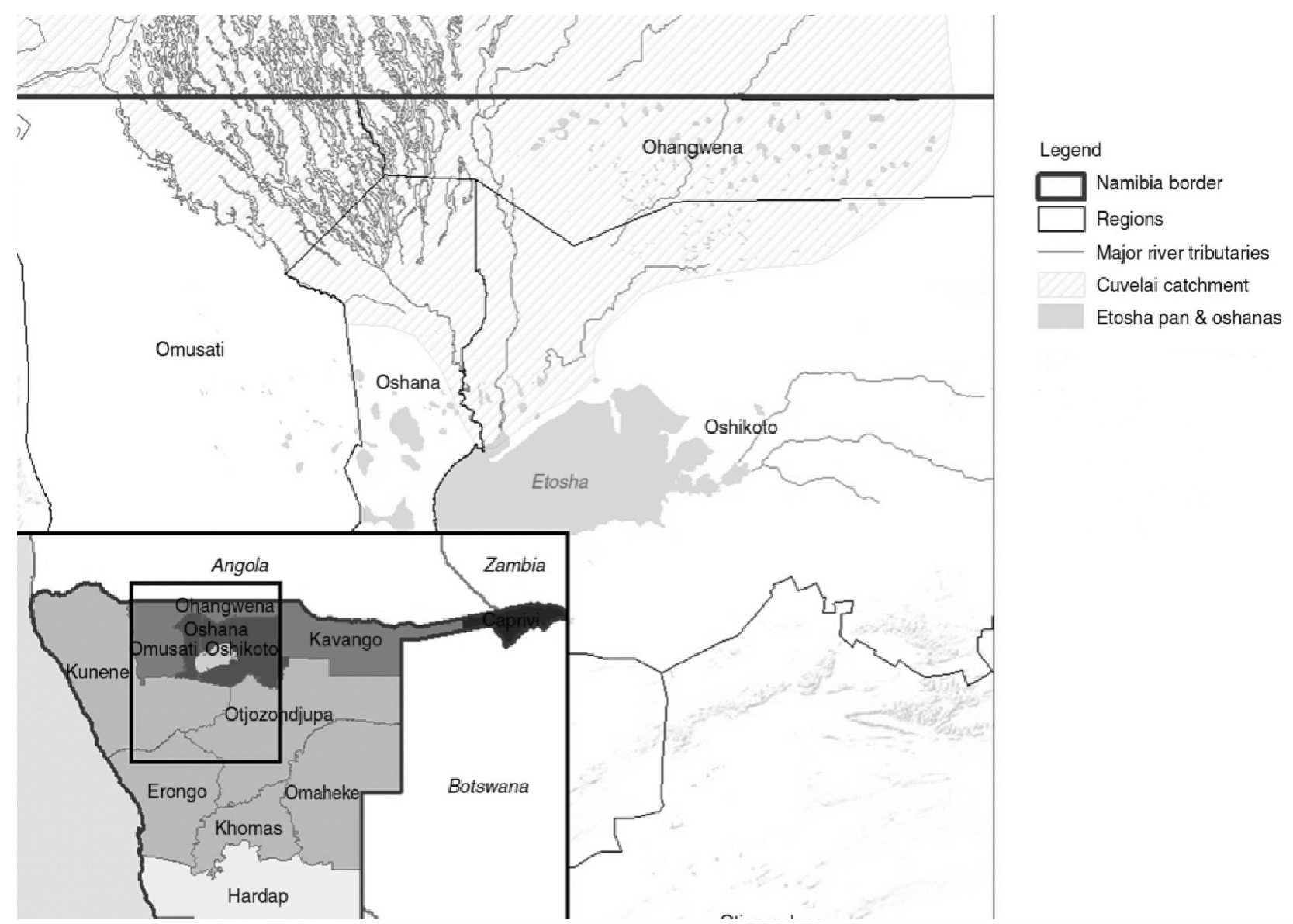

Fig. 1 Cuvelai Catchment system extending from southern Angola to northern Namibia (redrawn from Anthonj et al. [9]).

clayey soils supporting extensive woodlands of $C$. mopane (Colophospermummopane) [7]. However, as Mendelsonet al. [1] has pointed out that not all soils within zones of higher potential are suited for crop growth due to local variations.

The basin supports a significant number of diverse wildlife. About 250-270 bird species are found in the ecosystem, of which 90 are wetland species. Large numbers of fish colonize the ephemeral wetlands during floods. The number of species increases from Etosha (5) to Oponono (7) and the Cuvelai (17). These fish are heavily utilized by the local people with estimates of up to $4,000 \mathrm{~kg}$ of fish caught in a $30 \mathrm{~km}$ section in 1 day. The total harvest is unknown. In addition, 16 out of the 52 amphibian species known or expected to occur in Namibia are found in the Cuvelai Basin [10].

Predominantly, north central Namibia is characterized bythe Acacia-Tree and Shrub Savannabiomeswhich are mainly dominated by almost pure stands of C. Mopane [1]. The Iishanaare mainly covered by grass species, however, a few Makalanipalm trees (Hyphaenepetersiana) and Diospyrosmespiliformis can be found on the higher grounds within the channel networks. Some parts of the Iishana are either bare and mainly consist of sandy soils or sparsely covered by low lying vegetation species. These characteristics may be due to high levels of salinity as a result of high evapotranspiration of lengthy standing water in shallow ponds within the channel systems. Vegetation types found in different parts of the basin are closely correlated to variations in soils, occurrence of frost and the amount of rainfall received. Common grasses in the Iishana include: Sporoboluscoromandelianus,

Diplachnespp, Eragrotisrotifer, E. viscosa, Brachiariadeflexa and 
Elytrophorusglobularis. Sedges characteristic of these habitats include Cyperushalpan and Kyllingaalbiceps. Colophospermummopane and perennial grasses such as Willkommiasarmentosa, Eragrotistrichophora and Sporobolusioclados grow along the drier edges of the Iishana. A fuller description of the Iishana vegetation can be found in Mendelsohn et al. [1, 3], respectively.

The farming system across north-central Namibia is predominantly rain-fed, and is based on a crop component, with pearl millet (Pennisetumglaucum) as the staple crop, substituted with maize and sorghum in much smaller quantities. These cereals are supplemented by vegetables and legumes, most commonly beans, cowpeas, bambara nuts, groundnuts, pumpkins and melons, and more rarely spinach, cabbages and tomatoes. Fruit trees-especially Berchemia discolorand Sclerocaryabirrea provide wild fruit resources to supplement agricultural produce and livestock as a key component, resulting in an "agro-silvo-pastoral system". Diversification is perceived as a strategy of coping with low soil fertility and high rainfall unpredictability [11]. Farm holding sizes vary but averaging to 3.2 ha. This average masks significant variation, with wealthier farmers holding up to 10 ha and poorer ones less than 1 ha [12-14]. The farming system also comprises of livestock component (cattle, goats and donkeys), and a mixture of multipurpose indigenous trees and shrubs.

\subsection{The Owambo Indigenous Land Management System}

The Owambo farmers, as the early settlers of the Cuvelai Basin of north-central Namibia have been reported by many authors [11-15] to employ IEK (indigenous environmental knowledge) as the basis for making decisions about cropping, livestock grazing strategies and natural resources management. Therefore, it can be stated that IEK constitutes adaptive capacity to cope with the adverse effects of drought and flood events, giving local people resilience for centuries to drought and flooding variability impacts. As defined by Verlinden and Dayot [11], "indigenous environmental knowledge is referred in its broadest sense, relative to livelihoods, as accumulated knowledge, skill and technology of local people derived from their direct interaction with the environment that are passed on through generations". The IEK includes among others perceptions and explanations on geomorphology, landscape classifications, settlement strategies, crop production and fruit tree management [11]. When the Owambo people decided on where to graze animals or grow crops, they draw upon a sophisticated understanding of the productive potential of their environment, which includes (but not limited to) considerations of topography, elevation, soil properties, soil depth to the hardpan, soil-water dynamics and availability of annual and perennial grasses. This is referred to as an "indigenous land unit management classification system", and is described to aid decisions about what to plant and where, or about the management of a rangeland, and also as a central factor in determining settlement patterns $[13,16]$.

The Owambo utilized their indigenous environmental knowledge system to classify land and natural resources into land units for different land practices. Familiar landforms or land units are like plains, hills, valleys and flood plains "Iishana". One study conducted in a community forest within the Cuvelai Basin, made use of indigenous land units as sampling units in order to analyze their influence on floristic diversity, composition and structure in Uukolonkadhi community forest (Fig. 2) [15]. This study indicated strong evidence that indigenous land units in the forest are distinctly different in both vegetation dynamics and land uses. Soil texture appeared to be the most underlying factor influencing the dynamics of the land units and had the greatest influence on the vegetation. It also suggested that management of the community forest needs to recognize the differences in vegetation associations and develop specific management options for the 
different land units according to their respective vegetation composition, structure as well as land uses. This clearly illustrates the need to integrate indigenous environmental knowledge into scientific knowledge.

Verlinden and Dayot [12] stressed that land unit system used in Northern Namibia can be compared with a conventional scientific classification system and some convergence could be found, especially with land units based on vegetation criteria. A number of different criteria are used to identify land units for different land uses. The two main indicators employed for these types of classifications, are "physical" and "perceptual" methods [12]. "Physical" criteria may refer to soil colour and texture, or to landscape characteristics such as elevation, vegetation structure or abundance of termite hills (the presence of the latter being associated with soil fertility). "Perceptual" criteria, not always identifiable through the senses, refer to soil-water relationships, the ease or difficulty of working the soil, the suitability of the land for cultivation, grazing or non-agricultural purposes, such as for use in building and pottery material.

The value and utility of the ILUs (indigenous land units) of the north-central Namibia was demonstrated by Verlindenet al. [13], when applying a detrended correspondence analysis using vegetation criteria (Structure). The resulting information thereof demonstrated at the time, that such land units do not overlap, but form consistent classification categories which capture what in scientific terms would be seen as key ecological characteristics, in terms of vegetation species and structure, of the environment which they describe. In another study on land units favoured for cattle grazing, Verlinden and Kruger [17],

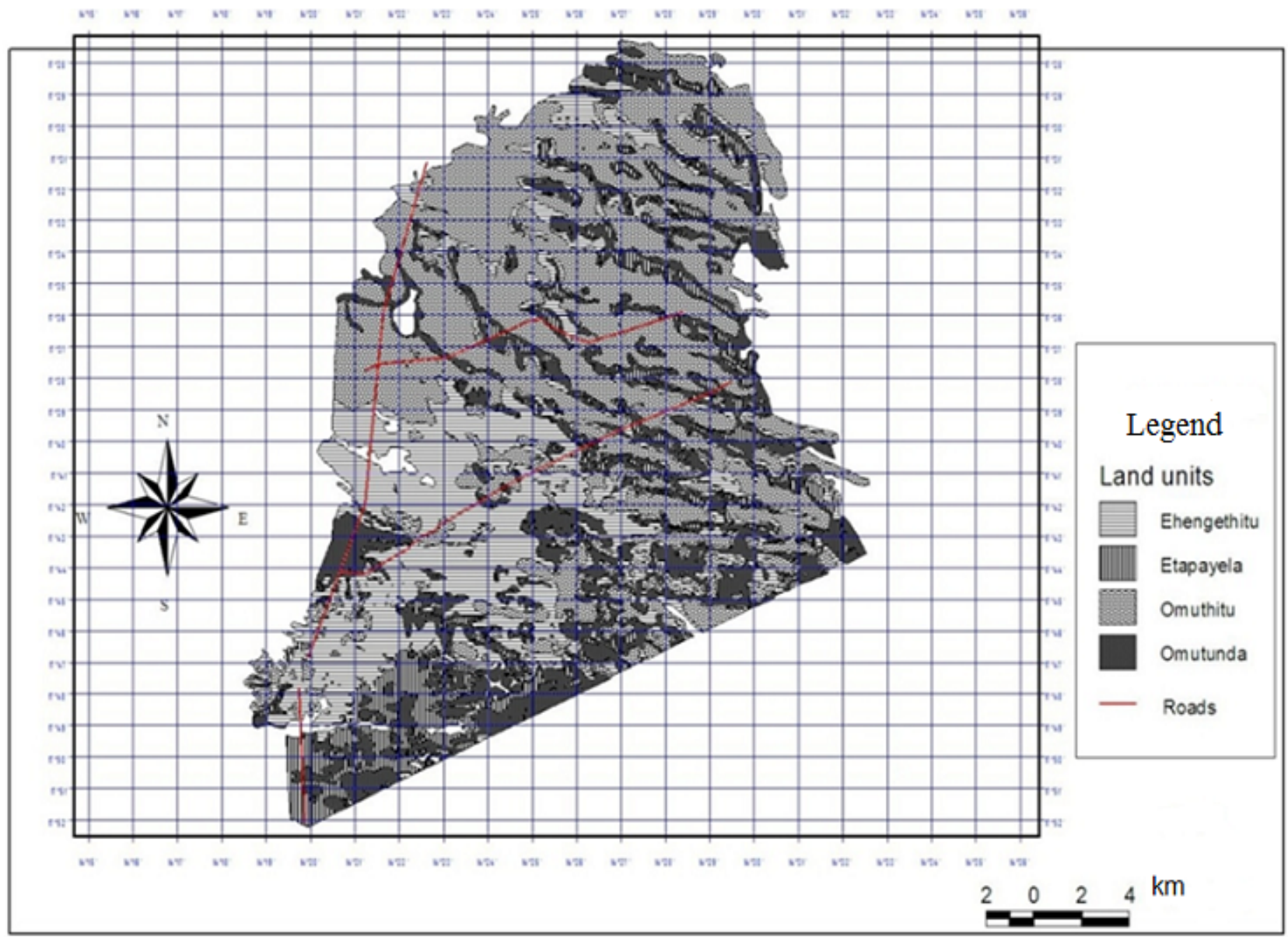

Fig. 2 Generalized indigenous land units in the Uukolonkadhi community forest, western part of Omusati Region, Namibia, which were used as sampling strata [15]. 
compared the land unit system with the results of CCA (canonical correspondence analysis) and concluded that it was "consistent with the ordination diagram of a CCA and most species indicators were reliable and in agreement with published data. Therefore, it can confidently be inferred that the indigenous land unit system of the north-central Namibia is consistent with scientific classification system and can be used as a management tool for informed decision making on policy formulation and management strategies.

As illustrated in Table 1, Verlinden and Dayot [12] distinguished three broad classes of indicators employed in the identification of indigenous land units: soil, vegetation and landform. Each of these indicator classes is comprised of sub-indicators, such as texture or hardpan depth for soil, species and structure for vegetation, and elevation or depression for landform. On this basis, particular land units have come to be associated with particular crops under particular conditions. For instance, ehengethitu, an indigenous land unit found and characterized by depressions in the landscape, is a desirable location for planting pearl millet in drier growing seasons. In wetter growing seasons, however, farmers often prefer to plant pearl millet in omutunda, a land unit characterized primarily by elevation, and which is held also to be more fertile. In contrast, other land units such as the sandy, dry and well-drained omufitu tend to be reserved for legumes such as bambara groundnuts, where farmers would expect little yield from a pearl millet crop [16]. Critically, the stability of crop production is enhanced when farms are comprised of a mixture of two or more land units. Precisely because it allows farmers to adapt their cropping strategies across a variety of growing season conditions ranging from dry to wet. It is for this reason that the indigenous land unit system is an important determinant in settlement patterns, as people settlein places which they can gain access to more than one land units, mostly prized for agricultural purposes [18]. This was supported by Hillyeret al. [16], using landsat imagery and aerial photography to produce a map of one of the villages in north central Namibia.

Table 1 Selected ILUs of Omusati Region with their vegetation, land forms, crops grown and soil characteristics (adapted from Refs. [11, 19]).

\begin{tabular}{|c|c|c|c|c|}
\hline ILUs & Vegetation characteristics & Land form & Crops grown & Soil characteristics \\
\hline Omuthitu & $\begin{array}{l}\text { Wooded area with } \\
\text { Baikiaeaplurijugaand other } \\
\text { tree species }\end{array}$ & Either plain or dune & $\begin{array}{l}\text { Pearl millet, beans, maize, } \\
\text { nuts, pumpkin, and melons }\end{array}$ & Sandy soils, brown to red \\
\hline Ehengethitu & $\begin{array}{l}\text { Wooded shrubland without } \\
\text { Baikiaeaplurijuga }\end{array}$ & Sand plain & $\begin{array}{l}\text { Bambara nuts, pearl } \\
\text { milletand beans }\end{array}$ & $\begin{array}{l}\text { Hard pan within reach of } \\
\text { tree roots, sand to loamy } \\
\text { sand }\end{array}$ \\
\hline Etapayela & $\begin{array}{l}\text { Trees and shrubs with } C \text {. } \\
\text { mopane, but without } \\
\text { Baikiaeaplurijugaand } \\
\text { Combretumcollimun }\end{array}$ & $\begin{array}{l}\text { Depressions larger than } \\
\text { ekango }\end{array}$ & Pearl millet, beans, melons & $\begin{array}{l}\text { Clayey soil mixed with } \\
\text { calcrete peddles and stones }\end{array}$ \\
\hline Omutunda & $\begin{array}{l}\text { Trees and shrubs with } C \text {. } \\
\text { mopane }\end{array}$ & $\begin{array}{l}\text { Elevation in ekango vicinity } \\
\text { or isolated plain, termite } \\
\text { mounts, pronounced slope }\end{array}$ & Pearl millet & $\begin{array}{l}\text { Hard pan presence, sandy } \\
\text { loamy to sand clay loamy } \\
\text { soils }\end{array}$ \\
\hline Endambo & Scattered large trees & Small depressions & Sorghum, melons and maize & $\begin{array}{l}\text { Dark Clay soils, holds } \\
\text { surface water in wet season }\end{array}$ \\
\hline Ekango & $\begin{array}{l}\text { No vegetation in Oshana } \\
\text { system, or covered by } \\
\text { shrubs outside } \\
\text { Oshanasystem } \\
\end{array}$ & $\begin{array}{l}\text { Depressions larger than } \\
\text { Endambo }\end{array}$ & Sorghum, melons and maize & $\begin{array}{l}\text { Light grey or white clay } \\
\text { soils with lime; } \\
\text { waterlogging in wet season }\end{array}$ \\
\hline Oshikurundu & Wooded shrubland & Ridges of rock outcrops & None & $\begin{array}{l}\text { Calcrete outcrops occurring } \\
\text { as small ridges }\end{array}$ \\
\hline Ondundu & Diverse vegetation & Stony hills & None & Stony hills \\
\hline
\end{tabular}


The map superimposes farm boundaries on top of a delineation of each of the land units in that area. The authors demonstrated that farms are more often composed of a number of land units, as opposed to being on the one land unit perceived to be most fertile, even where this would have been a perfectly feasible settlement option (Fig. 2). The categories of the land unit system also identify those features of the landscape which are most conducive for cattle grazing. Verlinden and Kruger [17] documented that Omutunda and Omuthituand unit are mostly used as grazing areasin Oshikoto region, but as noted above, also popular for cultivation. Different land uses could therefore find themselves in competition.

According to Newsham and Thomas [18], it is emphasized that Omutundais valued for its low tree cover and higher nutrient content, whilst omuthitu was viewed as an important grazing resource especially in the dry season. It is also reported that other land units were all known for offering grazing opportunities of differing quality depending upon the time of year and quantity of rains received. Assessing the settlement strategies using ILUs Verlinden et al. [13] pointed out, that farming in north-central Namibia, is not based on a single environmental factor, but based on holistic aspects of soil fertility, drainage properties, plant indicator species, termite activity, micro relief and landform. So people do not select primarily the most fertile ILUs, but other factors such as closeness to water come into play. In general, the more diverse a landscape is the better. Having wide range of ILUs responding differently to a range of rainfall scenarios is advantageous in semi-arid areas with a high variability in rainfall. There is also a trade-off between cropping and livestock rearing, termite activity and homestead longevity.

\subsection{Departure from Owambo Indigenous Land Management System and Its Impacts}

Unsurprisingly, change is one factor that can never be avoided, especially when it comes to the state of the environment. It should be noted that environmental conditions are dynamic and can change both in space and over time. However, change in most cases has been instigated by human activities and the management systems they employ [18]. Much of the changes taking place in the Cuvelai Basin can be attributed to increase in human population and the accompanying livestock numbers. It is worth noting that the population of the Cuvelai has grown from approximately 100,000 (1850) to 780,000 (2001) and is estimated to be 840,000 based on the 2011 household census $[2,8,20]$. Early settlements in the Cuvelai were based on the availability of water and suitable habitation for crop production, grazing and household construction, and shifting cultivation was practiced. In recent times, shortage of land among other social-economic and political factors has forced a shift in favour of permanent settlements. The reasons for this shift are that north-central Namibia has been experiencing an influx of people and sprawling of unplanned urban settlements in the past 2 decades. The origin of most urban centres in the basin was initially focused around goods and services provision. These areas have become commercial centres, attracting young people from rural areas with the hope of finding employment [3]. These newly adopted patterns have significantly contributed to environmental changes, either negatively or positively [21]. On the positive, increasing urban centres yield benefits from commercial and economic growth in the regionsin return providing economic opportunities to the basin inhabitants [3]. On the negative, however, these growths have been so substantial leading to the development of large metropolitan areas between major towns and settlements whereby infrastructures are being constructed in waterways, thereby creating water blockages in major ephemeral water channels and consequently resulting in increased salinization (Fig. 3).

According to Mendelsohn et al. [3], increase in population density meant that more land need to be 


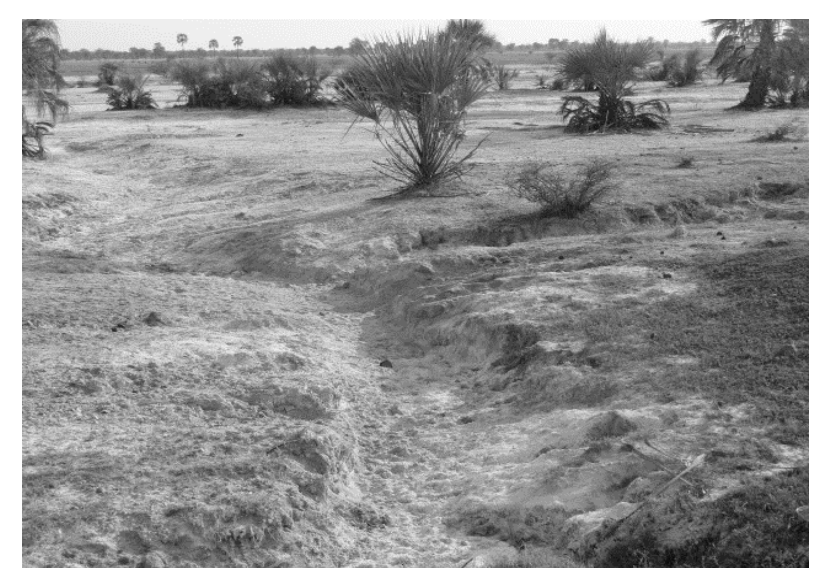

Fig. 3 Salinization resulting from blockage of water ways in Omusati region, north-central Namibia (photo: compliments of Dr. J. Njunge).

cleared for housing and farmlands. More trees had to be cut down. In the past, population density was relatively small, even though more children were born per family. The natural balancing of the population could have been attributed to the absence of health care facilitiesat the time, which meant that the majority of people died before reaching old age and more infants would die before reaching a certain age. With improved health care services, it meant that there was an increase in life expectancy and a decrease in infant mortality, thus gradually increasing the population density. As the population increased, so did the demand for land and natural resources. The demand for timber which was and still is used as construction materials has increased, leading to deforestation and in return land degradation.

Presently there has been a change in terms of land use systems. Changes have mainly taken place in the farming sector and household construction. Initially households and farmlands were strategically located on sandy mounts found among the Iishana water channels. This was done so as to prevent destructions from flooding during high rainfall periods and because these areas were considered to be fertile and therefore suitable for crop cultivation [22]. Today, since all suitable lands have been taken up crop fields are spreading into more marginal areas like infertile sand dunes and poorly drained areas bordering the iishana.
The consequences of this spread of crop fields to marginal areas, is frequent crop failures and widespread damage of crops in years of floods. Provision of relief food is becoming a common phenomenon in north-central Namibia.

Another factor contributing to the departure from Owambo indigenous land management system is changes in customary land rights and their implementation. Before the passing of the Communal Land Reform Act (Act No. 5 of 2002), chiefs and headmen were responsible for allocating land use rights to their people. In the past, the land belonged to tribal chiefs but was administered by village headmen and resources on the land such as grazing, water and forest products were commonly shared by members of that specific community. Settlements and cattle posts within the tribal areas were allocated by headmen to individuals according to the rules and norms embedded in the indigenous land management system. Due to population increase, traditional authorities inadequately regulated the allocation of land, resulting in reported cases of unequal land distribution in all communal areas. Some people were allocated huge pieces of land whereas others were getting less: some were allowed to fence their land, whereas others were not. This inevitably led to a lack of trust in the entire customary system of land tenure. In addition, there was increase in cases of double land allocations (whereby the same parcel of land is allocated to two or more different people), unauthorized extensions of allocated land and illegal fencing. These factors led to many land-related disputes, especially boundary disputes. Therefore, the Ministry of Lands and Resettlement drafted and enacted the Communal Land Reform Act in order to regulate the management, administration and the facilitation of a proper and uniform land registration system for all communal lands in Namibia, thereby minimizing the number of land disputes in communal areas [23].

Currently, land in communal areas belongs to the state, but people are given rights to use parts of these 
communal lands for a period of 99 years or as long as they live, and to pass on those rights to their descendants [23]. The Land Reform Act also regulates the powers of traditional authorities over communal land and establishes regional communal Land Boards that control the allocation of customary land rights by chiefs and headmen. The Land Boards grant, record, and cancel land rights in consultation with the traditional authorities. According to the Traditional Authorities Act 25 of 2000 , chiefs and headmen are recognized as legal entities and it provides for their designation as leaders, and defines their powers and duties. Traditional authorities have the obligation to supervise and ensure observation of customary law, to assist the local government with development of land-use plans, and to ensure that their communities are using natural resources in a sustainable manner [24]. Unfortunately, the implementation of these laws and policies puts little emphasis on the IEK during land allocation rather other factors like need for urban centres and the willingness of people to take up any vacant land irrespective of its suitability seem to be the key drivers of the system.

\subsection{Possible Ways of Preserving and Utilizing the Indigenous Knowledge}

Educating local communities about appropriate land use systems is the key to sustainable land management. Indigenous knowledge can be preserved by merging it with scientific knowledge. It can also be preserved by utilization of such knowledge through increased capacity for governance over resources for which indigenous people have shared responsibility. This will ideally enhance the relationships between the people and those supporting indigenous land management activities. Furthermore, indigenous knowledge can be embedded into policies and frame works that are directly concerned with land management systems. General education to the Cuvelai Basin inhabitants on the value of indigenous knowledge based land units is required. Such awareness will make inhabitants appreciate that departure from these systems has adverse consequences. Seminars can be conducted on causes of depletion of soil nutrients, soil compaction, salinization, falling crop yields, crop losses to floods and other land management challenges stemming from violating the indigenous knowledge on land management.

Authorities involved in issuing of land use rights and land use planning should be well grounded in indigenous knowledge on land management. Such authorities should be at the forefront of educating the masses on the importance of these systems as well as enforcing the existing policies and regulations rather than being agents of departure from utilizing the indigenous knowledge. Indigenous knowledge based land management ought to be in the curricula of agricultural programmes and other land planning courses. Model settlements based on this indigenous knowledge such as that of the Uukolonkadhi community can be used for demonstrating the value of indigenous knowledge systems and for practical training on utilization of this knowledge.

\section{Conclusions}

This paper has attempted to explicitly describe the indigenous land use system used by early settlers in the Namibian Cuvelai Basin that was in harmony with the biophysical characteristics of the land. Their indigenous environmental knowledge enabled them for many centuries to minimize the frequent impacts of drought and floods that the region had experienced. Indigenous land use systems have gradually been changing over the years, as people gradually diverted from local based land use and management systems. Progressively, this shift has resulted in the rapid utilization of natural resources, and eventually into degradation of the environment and consequently reduction in its ability to sustain inhabitants of the Cuvelai Basin. The increasing departure from the traditional way of managing land is typically due to 
population increase, whereby traditional chiefs and headmen inadequately regulated the allocation of land, departing from traditional norms and values, and eventually resulting in unauthorized extensions of allocated land, illegal fencing and many land-related disputes. The increase in population size has resulted in various environmental challenges such as deforestation and overgrazing, leading to further land degradation. The resultant impacts are mainly due to an increase in farmlands moving towards marginal areas and in return reducing land productivity due to nutrient depletion. The blocking of water channels through construction and agricultural activities has also contributed to degradation by increasing salinization and flooding during years of heavy rainfall. The pattern of setting up permanent settlements has shifted from one in harmony with topographical and edaphic factors and resilient over time, to one determined by economic reasons whereby the focus is establishment of commercial centres which in turn, attract an influx of people around them resulting in infrastructures being constructed in waterways, thereby creating water blockages in major ephemeral water channels.

Although most indigenous land use and management systems have been widely documented, they need to be embedded within government policies and regulations concerned with environmental management and strictly enforced. Lacking of enforcement explains why there is an increase in land degradation even decades after the passing of many environmental policies and regulations in Namibia. "Tragedy of the commons" is another reason for departure from sustainable land uses, whereby people are aware of consequences resulting from their activities, however they are in no hurry to make any change, reason being that the areas of operations are within communal lands were they do not have individual user rights. Finally, there is need for designing strategic basin management plans that are a combination of both scientific and indigenous knowledge.

\section{References}

[1] Mendelsohn, J., Jarvis, A., Roberts, C., and Robertson, T. 2002. Atlas of Namibia: A Portrait of the Land and its People. Cape Town. David Philip Publishers.

[2] Republic of Namibia. 2012. "Namibia 2011 Population and Housing Census: Preliminary Results." National Planning Commission. Accessed March 112014. http://www.npc.gov.na/npc/census_data.html.

[3] Mendelsohn, J., Jarvis, A., and Robertson, T. 2013. A Profile and Atlas of the Cuvelai-Etosha Basin. Windhoek: John Meinert Printing.

[4] Mendelshon, J., Obeid, S., and Roberts, C. 2000. A Profile of North-Central Namibia.Windhoek: Macmillan Publishers.

[5] Siiskonen, H. 1996. "Deforestation in the OwamboRegion North Namibia, since the 1850s." Environment and History 2 (3): 291-308.

[6] Kolberg, H. 2002. "Preliminary Inventory of Namibia's Wetlands." Directorate of Scientific Services. Ministry of Environment and Tourism, Windhoek, Namibia. Accessed August 29, 2014. http://www.drfn. info/arc/pdf/reprints/drfn2979.pdf.

[7] Mendelsohn, J., and Weber, B. 2011. "The Cuvelai Basin: Its Water and Its People." Research and Information Services of Namibia (RAISON), Windhoek, Namibia. Accessed April 13, 2015. http://www.raison.com. na/CUVELAI-Angola-Namibia/atlas/final_low.pdf.

[8] Kluge, T., Liehr, S., Lux, A., Niemann, S., and Brunner, K. 2006. IWRM in Northern Namibia-Cuvelai Delta .Final Report of a Preliminary Study.

[9] Anthonj, C., Nkongolo, O., Schmitz, P., Hango, J., and Kistemann, T. 2015. The Impact of Flooding on People Living with HIV: A Case Study from the Ohangwena Region, Namibia. Global Health Action volume 8. Accessed April 27, 2015. http://www.globalhealthaction. net/index.php/gha/article/view/26441.

[10] Kolberg, H., Griffin, M., and Simmons, R. 1996. "The Ephemeral Wetlands of Central Northern Namibia." Ministry of Environment and Tourism, Namibia. Accessed April 21, 2015.http://www.oceandocs. org/bitstream/1834/458/1/Africa_Wetlands_2.pdf.

[11] Verlinden, A., and Dayot, B. 2000. Indigenous Knowledge on the Environment in Northern Namibia: A Description of Land Units and Management. Windhoek and Northern Namibia Research and Extension Project (NOREESP), Ongwediva: National Remote Sensing Centre.

[12] Verlinden, A., and Dayot, B. 2005. "A Comparison between Indigenous Environmental Knowledge and a Conventional Vegetation Analysis in North Central Namibia." J. Arid Environ. 62 (1): 14-175. 


\section{A Case of Cuvelai Basin, North-Central Namibia}

[13] Verlinden, A., Seely, M. K., and Hillyer, A. 2006. "Settlement, Trees and Termites in Central North Namibia: A Case of Indigenous Resource Management." Journal of Arid Environments 66 (2): 307-35.

[14] Newsham, A. J., and Thomas, D.S.G. 2011. "Knowing, Farming and Climate Change Adaptation in North-Central Namibia." Global Environmental Change 21: 761-70

[15] Kaholongo, I. K., and Mapaure, I. 2014. "Vegetation Composition, Diversity, and Structure in Uukolonkadhi Community Forest of North Western Namibia." Journal of Agriculture and Biodiversity Research 3 (3): 41-50.

[16] Hillyer, A. E. M., McDonagh, J. F., and Verlinden, A. 2006. "Land-Use and Legumes in Northern Namibia-The Value of a Local Classification System." Agroculture, Ecosystems \& Environment 117 (4): 251-65.

[17] Verlinden, A., and Kruger, A. S. 2007. "Changing Systems in Central North Namibia." Land Degradation and Development 18: 179-97.

[18] Newsham, A., and Thomas, D. 2009. Agricultural Adaptation, Local Knowledge and Livelihood Diversification in North-Central Namibia. Working
Paper 140. Norwich, Tyndall Centre for Climate Change Research.

[19] Republic of Namibia. 2003. Inventory Report for Uukolonkadhi Community Forest Windhoek: National Forest Inventory Sub-component, Directorate of Forestry, Ministry of Environment and Tourism.

[20] Erkkila, A., and Siiskonen, H. 1992. Forestry in Namibia 1850-1990. Joensuu, University of Joensuu.

[21] De Wit, P., and Verheye, W. 2003. Land Use, Land Cover and Soil Science: Land Use Planning For Sustainable Development.Oxford, UK: United Nations Educational, Scientific and Cultural Organisation Encyclopedia of Life Support Systems Publishers

[22] Strengthening the Protected Area Network (SPAN). 2013. Conservation and the Environment in Namibia. Windhoek: John Meinert Printing.

[23] Government Republic of Namibia. 2002. Communal Land Reform Act, 2002 (Act No. 5 of 2002). Windhoek: Government Gazette No. 2787.

[24] Government Republic of Namibia. 2000. Traditional Authority Act, 2000 (Act No.25 of 2000). Windhoek: Government Gazette No. 2456. 